2016

\title{
The Frank Norris Farm Site (41RR2) on the Red River in East Texas
}

Timothy K. Perttula

Heritage Research Center, Stephen F. Austin State University

Mark Walters

Heritage Research Center, Stephen F. Austin State University

Follow this and additional works at: https://scholarworks.sfasu.edu/ita

Part of the American Material Culture Commons, Archaeological Anthropology Commons, Environmental Studies Commons, Other American Studies Commons, Other Arts and Humanities Commons, Other History of Art, Architecture, and Archaeology Commons, and the United States History Commons

Tell us how this article helped you.

This Article is brought to you for free and open access by the Center for Regional Heritage Research at SFA ScholarWorks. It has been accepted for inclusion in Index of Texas Archaeology: Open Access Gray Literature from the Lone Star State by an authorized editor of SFA ScholarWorks. For more information, please contact cdsscholarworks@sfasu.edu. 


\section{The Frank Norris Farm Site (41RR2) on the Red River in East Texas \\ Creative Commons License \\ (c) (1) \& 8}

This work is licensed under a Creative Commons Attribution-NonCommercial 4.0 International License 


\title{
The Frank Norris Farm Site (41RR2) on the Red River in East Texas
}

\author{
Timothy K. Perttula and Mark Walters
}

\section{INTRODUCTION AND SITE SETTING}

The Frank Norris Farm site (41RR2) was an ancestral Caddo settlement and mound center, with an associated cemetery, on the bank of the Red River, about five miles northeast of the community of Manchester, Texas, and just southeast of the Sam Kaufman/Roitsch site (41RR16) (Perttula 2008; Skinner et al. 1969) (Figure 1). The site was reported by B. B. Gardner of the University of Texas to have three earthen mounds. Apparently the site eroded into the Red River in 1936 (Figure 2a).

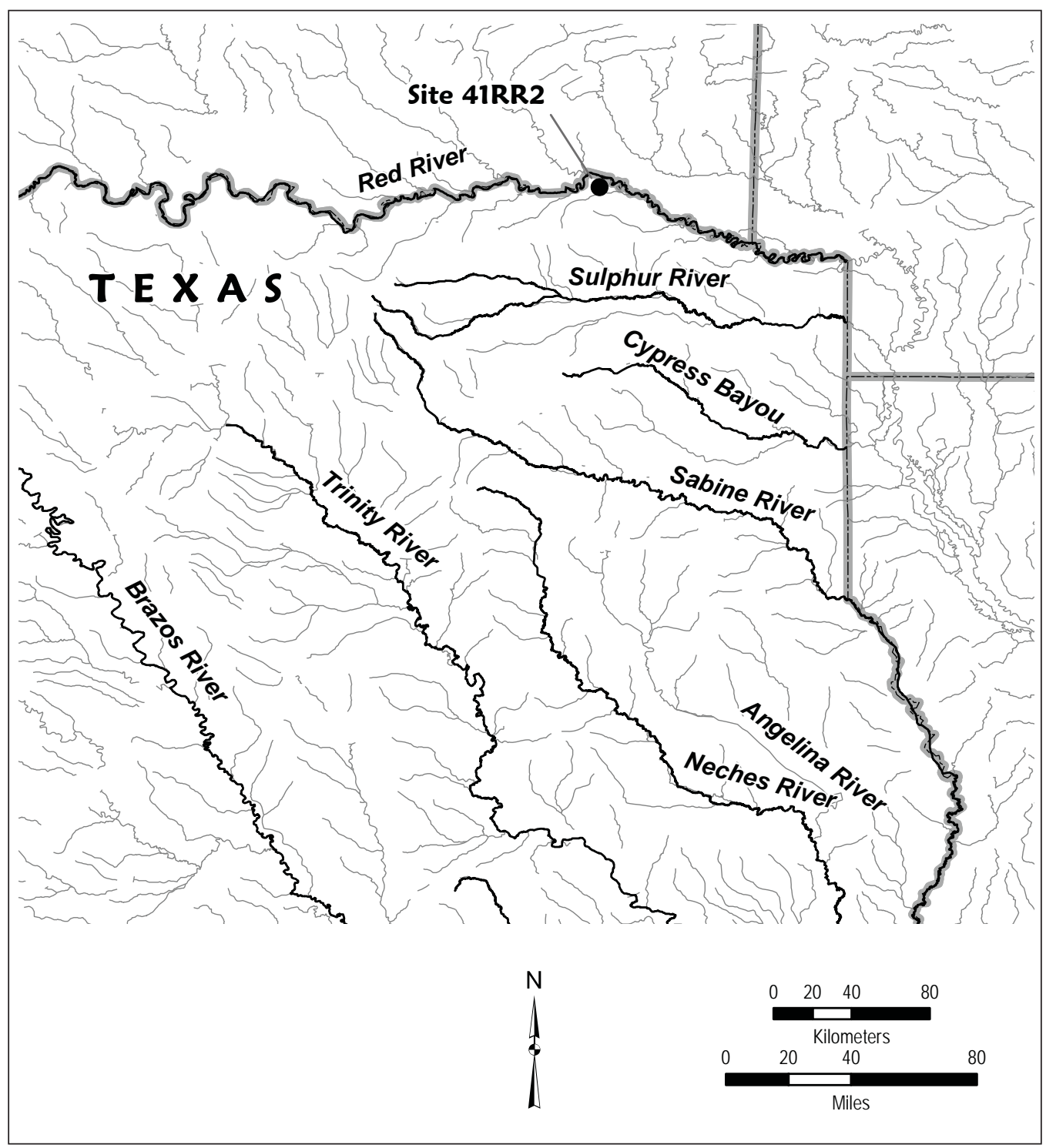

Figure 1. Location of the Frank Norris Farm (41RR2) in East Texas. 


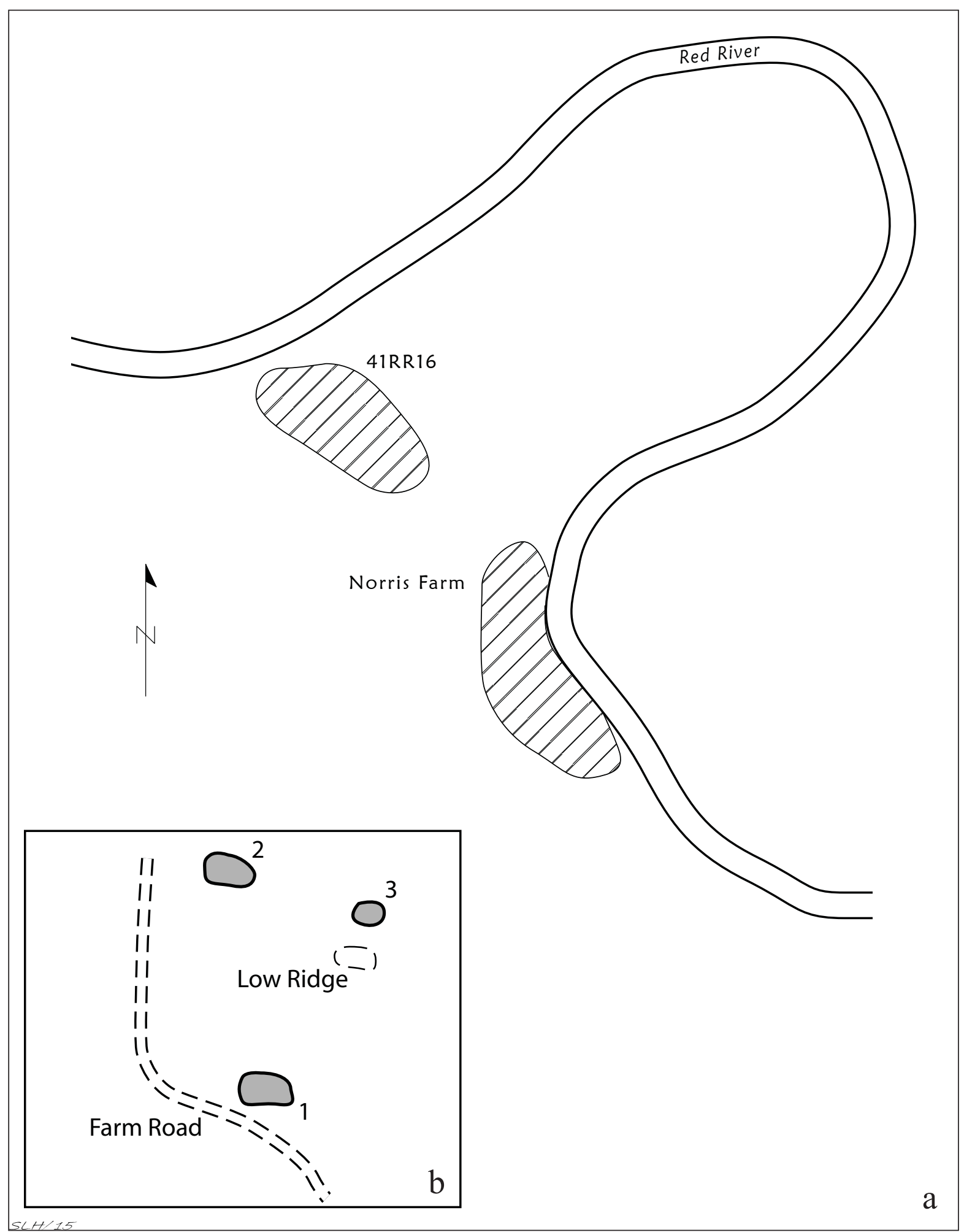

Figure 2. Maps of the Frank Norris Farm (41RR2) site: a, ca. 1970 map by R. King Harris; b, 1930 map by B. B. Gardner. 
The three mounds at the site were located east of a local farm road (Figure 2b), and the bank of the Red River was a short distance to the east. Mound No. 1 was ca. $27 \mathrm{~m}$ in length, $23 \mathrm{~m}$ in width, and $3 \mathrm{~m}$ in height; Mound No. 2 was ca. $33.5 \mathrm{~m}$ in length, $24 \mathrm{~m}$ in width, and $3.7 \mathrm{~m}$ in height; and Mound No. 3 was ca. $18 \mathrm{~m}$ in length, $12 \mathrm{~m}$ in width, and $1.8 \mathrm{~m}$ in height. Gardner trenched Mound No. 1 in the summer of 1930 but found only a few sherds and no obvious features. A low alluvial ridge not far south of Mound No. 3 was also trenched by Gardner, and he recovered sherds from archaeological deposits there.

Gardner also noted that in the Red River cut bank was an ca. 46-61 cm thick archaeological deposit with black sediments and ceramic sherds. Although Gardner's 1930 notes are not specific, he apparently excavated at least one burial at the Frank Norris Farm. Correspondence in the Texas Archeological Research Laboratory (TARL) files stated that Gardner found burials that were from 1.2-1.5 $\mathrm{m}$ in depth and scattered across the site.

Local diggers began to search out and excavate Caddo burials at the Frank Norris Farm site in 1934 and 1935, and these diggers sold the ceramic vessels and other funerary offerings (including a spatulate celt, arrow points, and shell beads) they found to local collectors like George T. Wright. According to W. A. Rikard, an interested avocational archaeologist from the region, at least nine burials had been found and dug by collectors at the site, not including the one or more burials he excavated there. He did mention in 1935 correspondence to A. T. Jackson that one burial he excavated was in a $1.2 \mathrm{~m}$ deep pit and had a shell-tempered neck banded jar as an associated funerary offering. He also noted that other Caddo burials were being exposed in the eroding cut bank of the Red River, where they were easily looted.

\section{Ceramic Vessels}

There are 12 vessels in the TARL collections from the Frank Norris Farm site. Seven vessels were obtained by B. B. Gardner of The University of Texas (UT) in work done at the site in 1930. The other five vessels were purchased by UT in 1934 and 1935 from W. A. Rikard of Paris, Texas. Howard Hampton (Hampton and Moore 1936) also reported on other vessels from the site, including an engraved effigy bowl $(6.2 \mathrm{~cm}$ in height, $15.0 \mathrm{~cm}$ in length, and the diameter of the bowl was $7.0 \mathrm{~cm})$ with a turtle-like head. The engraved bowl had cross-hatched zones and negative ovals. A cast of this vessel is in the collections at the Texas Archeological Research Laboratory at The University of Texas at Austin (Figure 3).
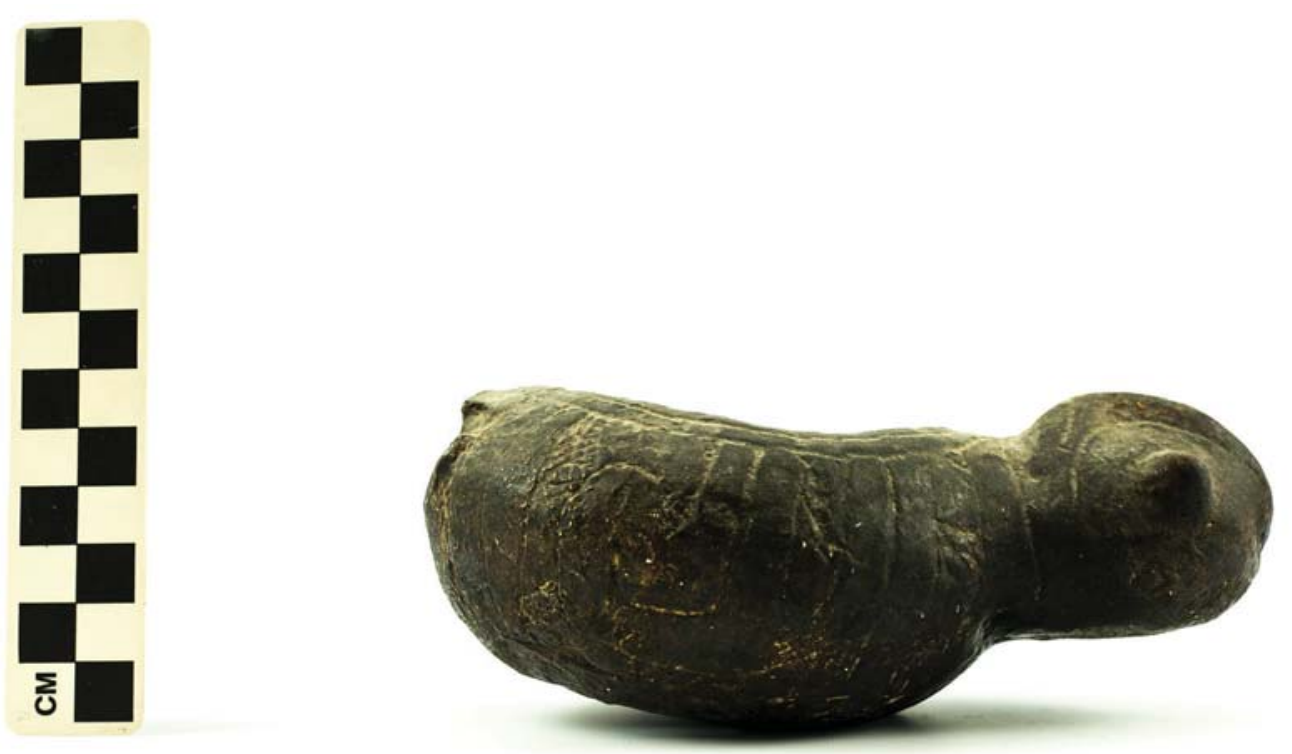

Figure 3. Engraved effigy bowl collected by Howard Hampton from the Frank Norris Farm site. Photograph courtesy of Robert Z. Selden Jr. 
SITE NAME OR SITE NUMBER: Frank Norris Farm (41RR2)

VESSEL NO.: 41RR2-1

VESSEL FORM: Jar

NON-PLASTICS AND PASTE: grog

RIM AND LIP FORM: Everted rim and rounded lip

CORE COLOR: F (fired in a reducing environment and cooled in the open air)

INTERIOR SURFACE COLOR: dark yellowish-brown; fire clouds on the rim and body

EXTERIOR SURFACE COLOR: yellowish-brown; fire clouds on the rim, body, and base

WALL THICKNESS (IN MM): rim, $7.5 \mathrm{~mm}$

INTERIOR SURFACE TREATMENT: smoothed

EXTERIOR SURFACE TREATMENT: smoothed on the body

HEIGHT (IN CM): 19.3

ORIFICE DIAMETER (IN CM): 14.0

DIAMETER AT BOTTOM OF RIM OR NECK (IN CM): 13.2

BASE DIAMETER (IN CM) AND SHAPE OF BASE: 10.3; circular and flat

ESTIMATED VOLUME (IN LITERS): 2.4

DECORATION (INCLUDING MOTIF AND ELEMENTS WHEN APPARENT): There are three closely spaced horizontal rows of fingernail punctations on the vessel rim.

PIGMENT USE AND LOCATION ON VESSEL: none

TYPE AND VARIETY (IF KNOWN): Unidentified utility ware

SITE NAME OR SITE NUMBER: Frank Norris Farm (41RR2)

VESSEL NO.: 41RR2-2

VESSEL FORM: Beaker with two opposed suspension holes (3.6-3.8 $\mathrm{mm}$ in diameter) on the upper part of the beaker

NON-PLASTICS AND PASTE: grog

RIM AND LIP FORM: Inverted rim and rounded lip

CORE COLOR: B (fired and cooled in a reducing environment) 
INTERIOR SURFACE COLOR: dark gray

EXTERIOR SURFACE COLOR: dark gray

WALL THICKNESS (IN MM): rim, 4.9 mm

INTERIOR SURFACE TREATMENT: smoothed

EXTERIOR SURFACE TREATMENT: smoothed

HEIGHT (IN CM): 10.0

ORIFICE DIAMETER (IN CM): 7.0

DIAMETER AT BOTTOM OF RIM OR NECK (IN CM): N/A

BASE DIAMETER (IN CM) AND SHAPE OF BASE: 6.9; circular and flat

ESTIMATED VOLUME (IN LITERS): 0.42

DECORATION (INCLUDING MOTIF AND ELEMENTS WHEN APPARENT): The vessel has four horizontal engraved lines on the upper part of the beaker, above the two opposed suspension holes.

PIGMENT USE AND LOCATION ON VESSEL: none

TYPE AND VARIETY (IF KNOWN): Hickory Engraved

SITE NAME OR SITE NUMBER: Frank Norris Farm (41RR2)

VESSEL NO.: 41RR2-3

VESSEL FORM: Bottle with a tapered neck

NON-PLASTICS AND PASTE: bone

RIM AND LIP FORM: Direct rim and a rounded lip

CORE COLOR: $\mathrm{F}$ (fired in a reducing environment and cooled in the open air)

INTERIOR SURFACE COLOR: reddish-brown (at the neck)

EXTERIOR SURFACE COLOR: red; fire clouds on the body

WALL THICKNESS (IN MM): rim, $5.3 \mathrm{~mm}$

INTERIOR SURFACE TREATMENT: none

EXTERIOR SURFACE TREATMENT: burnished

HEIGHT (IN CM): 23.7 
ORIFICE DIAMETER (IN CM): 3.8

DIAMETER AT BOTTOM OF RIM OR NECK (IN CM): 7.8; maximum body diameter is $12.3 \mathrm{~cm}$

BASE DIAMETER (IN CM) AND SHAPE OF BASE: 8.0; circular and rounded

ESTIMATED VOLUME (IN LITERS): 0.76

DECORATION (INCLUDING MOTIF AND ELEMENTS WHEN APPARENT): There is a red slip applied to the exterior bottle surface.

PIGMENT USE AND LOCATION ON VESSEL: none

TYPE AND VARIETY (IF KNOWN): Sanders Slipped

SITE NAME OR SITE NUMBER: Frank Norris Farm (41RR2)

VESSEL NO.: 41RR2-4

VESSEL FORM: Jar

NON-PLASTICS AND PASTE: grog

RIM AND LIP FORM: Everted rim and rounded lip

CORE COLOR: $\mathrm{G}$ (fired in a reducing environment and cooled in the open air)

INTERIOR SURFACE COLOR: very dark grayish-brown

EXTERIOR SURFACE COLOR: yellowish-brown

WALL THICKNESS (IN MM): rim, $6.5 \mathrm{~mm}$

INTERIOR SURFACE TREATMENT: smoothed

EXTERIOR SURFACE TREATMENT: none

HEIGHT (IN CM): 17.9

ORIFICE DIAMETER (IN CM): 15.2

DIAMETER AT BOTTOM OF RIM OR NECK (IN CM): 14.2

BASE DIAMETER (IN CM) AND SHAPE OF BASE: 8.4; circular and flat

ESTIMATED VOLUME (IN LITERS): 2.4

DECORATION (INCLUDING MOTIF AND ELEMENTS WHEN APPARENT): The rim has six equallyspaced horizontal incised lines, while there are 53 diagonal to vertical incised lines on the vessel body (cf. Suhm and Jelks 1962:Plate 45a, d). These lines extend from the rim-body juncture to the vessel base. 
PIGMENT USE AND LOCATION ON VESSEL: none

TYPE AND VARIETY (IF KNOWN): Kiam Incised

SITE NAME OR SITE NUMBER: Frank Norris Farm (41RR2)

VESSEL NO.: 41RR2-5

VESSEL FORM: Carinated bowl

NON-PLASTICS AND PASTE: grog

RIM AND LIP FORM: Direct rim and rounded lip

CORE COLOR: A (fired and cooled in an oxidizing environment)

INTERIOR SURFACE COLOR: yellowish-brown; fire clouds on the body and base

EXTERIOR SURFACE COLOR: yellowish-brown; fire clouds on the body and base

WALL THICKNESS (IN MM): rim, $5.4 \mathrm{~mm}$; body, $6.1 \mathrm{~mm}$; base, $6.7 \mathrm{~mm}$

INTERIOR SURFACE TREATMENT: none

EXTERIOR SURFACE TREATMENT: smoothed

HEIGHT (IN CM): 4.8

ORIFICE DIAMETER (IN CM): 11.8

DIAMETER AT BOTTOM OF RIM OR NECK (IN CM): 11.8

BASE DIAMETER (IN CM) AND SHAPE OF BASE: 7.8; circular and flat

ESTIMATED VOLUME (IN LITERS): 0.34

DECORATION (INCLUDING MOTIF AND ELEMENTS WHEN APPARENT): The rim panel has a series of closely-spaced diagonal (pitched in opposing directions) and vertical engraved lines, with each series divided by large excised pendant triangles (Figure 4; cf. Suhm and Jelks 1962:Plates 39a, e and 40a).

PIGMENT USE AND LOCATION ON VESSEL: none

TYPE AND VARIETY (IF KNOWN): Holly Fine Engraved

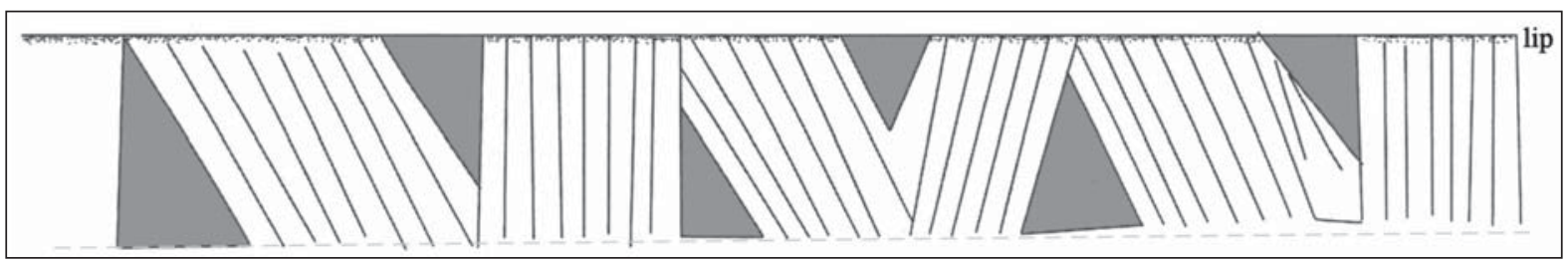

Figure 4. Decorative elements on Holly Fine Engraved carinated bowl from the Frank Norris Farm site (41RR2). 
SITE NAME OR SITE NUMBER: Frank Norris Farm (41RR2)

VESSEL NO.: 41RR2-6

VESSEL FORM: Bottle with a tapered neck

NON-PLASTICS AND PASTE: grog

RIM AND LIP FORM: Direct rim and a rounded lip

CORE COLOR: B (fired and cooled in a reducing environment)

INTERIOR SURFACE COLOR: grayish-brown

EXTERIOR SURFACE COLOR: very dark grayish-brown; fire clouds on the body

WALL THICKNESS (IN MM): rim, $5.6 \mathrm{~mm}$

INTERIOR SURFACE TREATMENT: none

EXTERIOR SURFACE TREATMENT: burnished

HEIGHT (IN CM): 22.1

ORIFICE DIAMETER

(IN CM): 4.0

DIAMETER AT BOTTOM

OF RIM OR NECK

(IN CM): 6.6; maximum

body diameter is $8.1 \mathrm{~cm}$

BASE DIAMETER

(IN CM) AND SHAPE

OF BASE: 8.3;

circular and flat

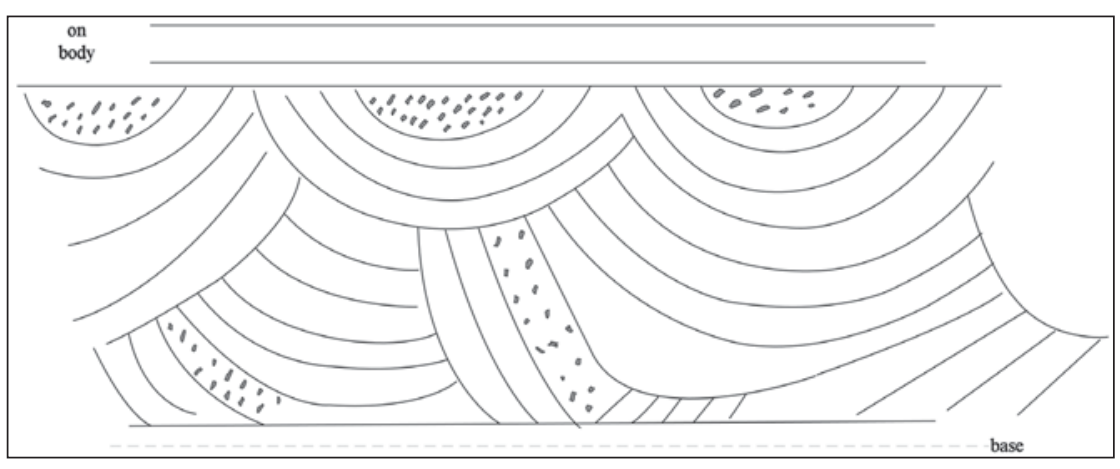

Figure 5. Decorative elements on Spiro Engraved bottle from the Frank Norris Farm site (41RR2).

ESTIMATED VOLUME (IN LITERS): 0.73

DECORATION (INCLUDING MOTIF AND ELEMENTS WHEN APPARENT): The vessel body has an engraved-punctated motif repeated four times around the vessel (Figure 5). There are three horizontal engraved lines on the body under the neck and a single horizontal engraved line above the vessel base. Between these horizontal engraved lines are a series of upper concentric semi-circles, with the innermost semi-circle filled with excised punctations. Connected to these upper concentric semi-circles are opposed zones filled with concentric lines as well as diagonal zones filled with excised punctations.

PIGMENT USE AND LOCATION ON VESSEL: red pigment in the engraved lines

TYPE AND VARIETY (IF KNOWN): Spiro Engraved 
SITE NAME OR SITE NUMBER: Frank Norris Farm (41RR2)

VESSEL NO.: 41RR2-7

VESSEL FORM: Bottle with a long and tapered neck

NON-PLASTICS AND PASTE: grog

RIM AND LIP FORM: Direct rim and flat lip

CORE COLOR: $\mathrm{F}$ (fired in a reducing environment and cooled in the open air)

INTERIOR SURFACE COLOR: reddish-brown (at the neck)

EXTERIOR SURFACE COLOR: red

WALL THICKNESS (IN MM): rim, 5.6 mm

INTERIOR SURFACE TREATMENT: none

EXTERIOR SURFACE TREATMENT: burnished

HEIGHT (IN CM): 22.9

ORIFICE DIAMETER (IN CM): 4.3

DIAMETER AT BOTTOM OF RIM OR NECK (IN CM): 7.0

BASE DIAMETER (IN CM) AND SHAPE OF BASE: 9.5; circular and flat

ESTIMATED VOLUME (IN LITERS): 0.86

DECORATION (INCLUDING MOTIF AND ELEMENTS WHEN APPARENT): There are four finely-drawn horizontal engraved lines on the vessel body, below the bottle neck (cf. Suhm and Jelks 1962:Plate 36c, f).

PIGMENT USE AND LOCATION ON VESSEL: none

TYPE AND VARIETY (IF KNOWN): Hickory Engraved

SITE NAME OR SITE NUMBER: Frank Norris Farm (41RR2)

VESSEL NO.: Red River General-79 (W. A. Rikard Collection)

VESSEL FORM: Jar with four appliqued lugs (16 x $13 \mathrm{~mm}$ in length and width) on the rim

NON-PLASTICS AND PASTE: shell

RIM AND LIP FORM: Everted rim and rounded lip

CORE COLOR: G (fired in a reducing environment and cooled in the open air) 
INTERIOR SURFACE COLOR: grayish-brown

EXTERIOR SURFACE COLOR: reddish-brown; fire clouds on the rim and body

WALL THICKNESS (IN MM): rim, $6.5 \mathrm{~mm}$

INTERIOR SURFACE TREATMENT: smoothed

EXTERIOR SURFACE TREATMENT: none

HEIGHT (IN CM): 13.8

ORIFICE DIAMETER (IN CM): 12.2

DIAMETER AT BOTTOM OF RIM OR NECK (IN CM): 9.6

BASE DIAMETER (IN CM) AND SHAPE OF BASE: 5.7; circular and flat

ESTIMATED VOLUME (IN LITERS): 1.0

DECORATION (INCLUDING MOTIF AND ELEMENTS WHEN APPARENT): There are four horizontal neck bands on the rim. On the vessel body are four vertical appliqued ridges that run from the rim-body juncture to $4.0 \mathrm{~cm}$ above the base

PIGMENT USE AND LOCATION ON VESSEL: none

TYPE AND VARIETY (IF KNOWN): Nash Neck Banded

SITE NAME OR SITE NUMBER: Frank Norris Farm (41RR2)

VESSEL NO.: 348-364 (W. A. Rikard Collection)

VESSEL FORM: Jar

NON-PLASTICS AND PASTE: grog

RIM AND LIP FORM: Inverted rim and flat lip

CORE COLOR: F (fired in a reducing environment and cooled in the open air)

INTERIOR SURFACE COLOR: dark yellowish-brown; fire clouds on the rim and body

EXTERIOR SURFACE COLOR: dark yellowish-brown; fire clouds on the rim, body, and base

WALL THICKNESS (IN MM): rim, $6.9 \mathrm{~mm}$

INTERIOR SURFACE TREATMENT: smoothed

EXTERIOR SURFACE TREATMENT: none

HEIGHT (IN CM): 9.5 
ORIFICE DIAMETER (IN CM): 8.3

DIAMETER AT BOTTOM OF RIM OR NECK (IN CM): 10.9

BASE DIAMETER (IN CM) AND SHAPE OF BASE: 7.6; circular and flat

ESTIMATED VOLUME (IN LITERS): 0.47

DECORATION (INCLUDING MOTIF AND ELEMENTS WHEN APPARENT): The vessel has 13

horizontal rows of tool punctations that extend from the rim to the vessel base.

PIGMENT USE AND LOCATION ON VESSEL: none

TYPE AND VARIETY (IF KNOWN): Unidentified utility ware

SITE NAME OR SITE NUMBER: Frank Norris Farm (41RR2)

VESSEL NO.: 348-365 (W. A. Rikard Collection)

VESSEL FORM: Bowl

NON-PLASTICS AND PASTE: shell

RIM AND LIP FORM: Direct rim and rounded lip

CORE COLOR: B (fired and cooled in a reducing environment)

INTERIOR SURFACE COLOR: very dark grayish-brown

EXTERIOR SURFACE COLOR: very dark grayish-brown

WALL THICKNESS (IN MM): rim, $4.6 \mathrm{~mm}$; body, $5.3 \mathrm{~mm}$; base, $9.0 \mathrm{~mm}$

INTERIOR SURFACE TREATMENT: smoothed

EXTERIOR SURFACE TREATMENT: smoothed

HEIGHT (IN CM): 5.6

ORIFICE DIAMETER (IN CM): 7.7

DIAMETER AT BOTTOM OF RIM OR NECK (IN CM): N/A

BASE DIAMETER (IN CM) AND SHAPE OF BASE: 5.4; circular and flat

ESTIMATED VOLUME (IN LITERS): 0.17

DECORATION (INCLUDING MOTIF AND ELEMENTS WHEN APPARENT): The lip of the vessel is notched. The entire exterior vessel surface has sets of opposed curvilinear trailed lines (Figure 6).

PIGMENT USE AND LOCATION ON VESSEL: none 
TYPE AND VARIETY (IF KNOWN): Keno Trailed

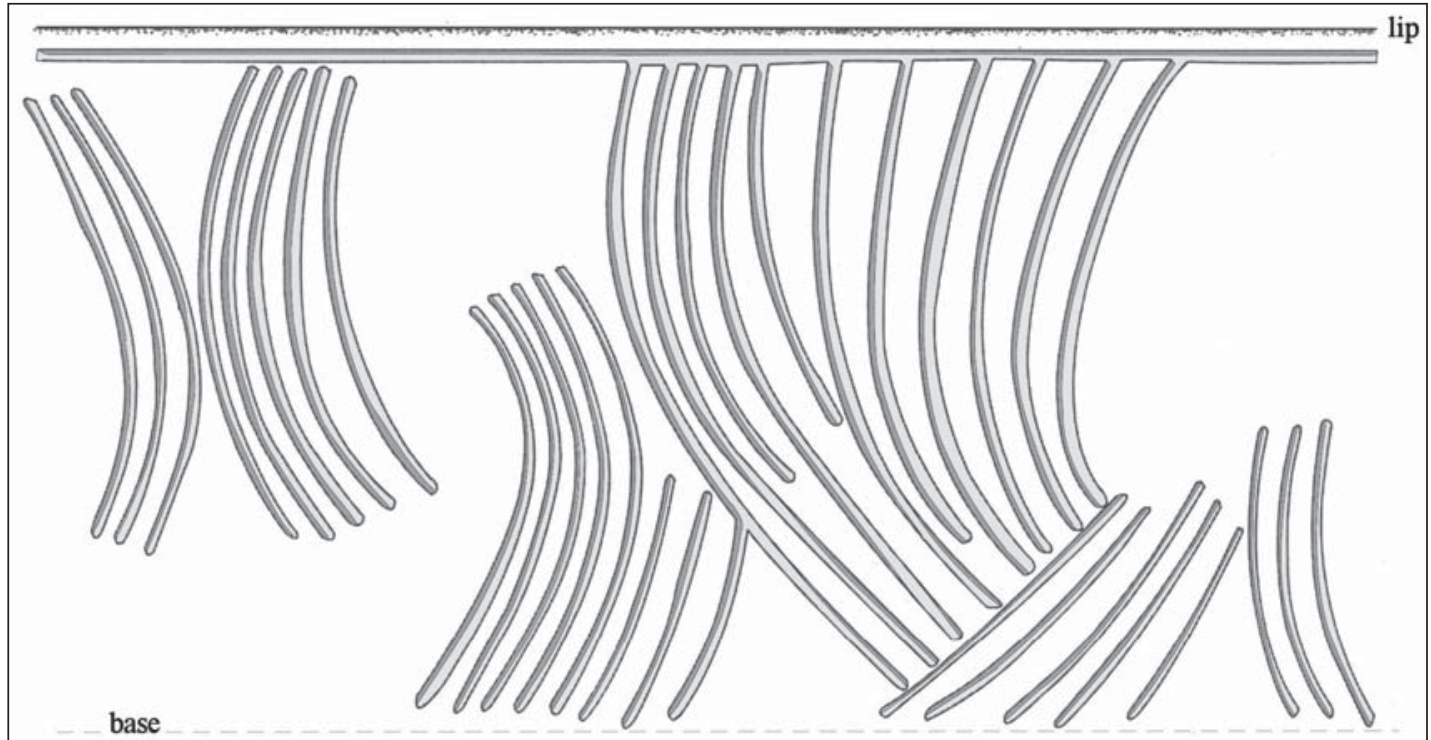

Figure 6. Decorative elements on Keno Trailed bowl from the Frank Norris Farm site (41RR2).

SITE NAME OR SITE NUMBER: Frank Norris Farm (41RR2)

VESSEL NO.: 348-368 (W. A. Rikard Collection)

VESSEL FORM: Jar

NON-PLASTICS AND PASTE: shell

RIM AND LIP FORM: Everted rim and rounded lip

CORE COLOR: $\mathrm{F}$ (fired in a reducing environment and cooled in the open air)

INTERIOR SURFACE COLOR: red

EXTERIOR SURFACE COLOR: red; fire clouds on the body

WALL THICKNESS (IN MM): rim, $5.3 \mathrm{~mm}$; body, $5.1 \mathrm{~mm}$

INTERIOR SURFACE TREATMENT: burnished

EXTERIOR SURFACE TREATMENT: burnished

HEIGHT (IN CM): 11.4

ORIFICE DIAMETER (IN CM): 15.0

DIAMETER AT BOTTOM OF RIM OR NECK (IN CM): 11.5

BASE DIAMETER (IN CM) AND SHAPE OF BASE: 8.9; circular 
ESTIMATED VOLUME (IN LITERS): 1.0

DECORATION (INCLUDING MOTIF AND ELEMENTS WHEN APPARENT): The vessel has an interior and exterior red-slipped surface. The rim has three widely-spaced horizontal lines, while the vessel body has four panels defined by sets of three vertical engraved lines. Within each panel is a large engraved pendant triangle bisected by a single vertical line. Either side of the vertical line within the triangle has diagonal opposed engraved lines (Figure 7).

PIGMENT USE AND LOCATION ON VESSEL: none

TYPE AND VARIETY (IF KNOWN): Unidentified fine ware

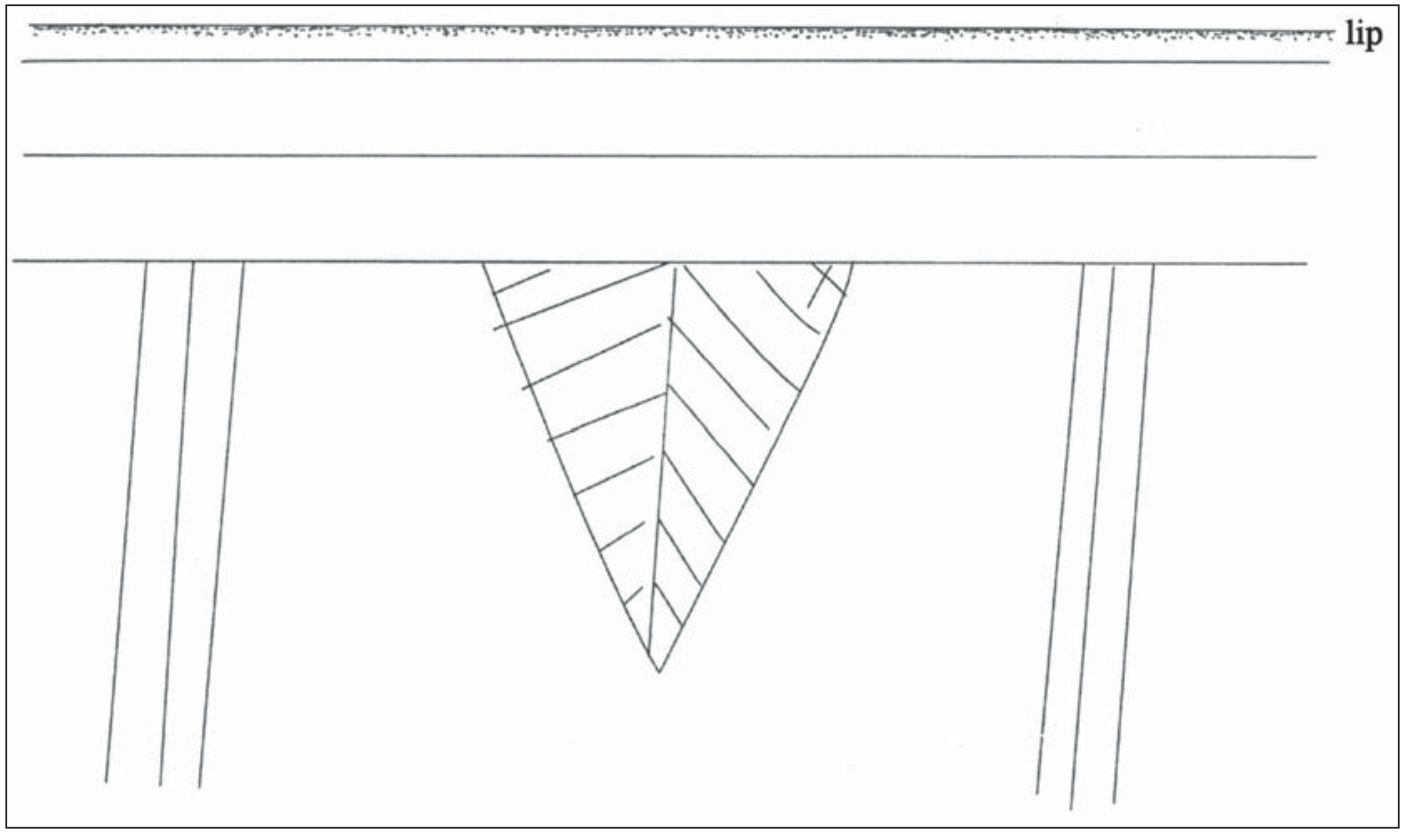

Figure 7. Decorative elements on engraved shell-tempered jar from the Frank Norris Farm site (41RR2).

SITE NAME OR SITE NUMBER: Frank Norris Farm (41RR2)

VESSEL NO.: 348-369 (W. A. Rikard Collection)

VESSEL FORM: Bowl

NON-PLASTICS AND PASTE: grog

RIM AND LIP FORM: Direct rim and rounded lip

CORE COLOR: G (fired in a reducing environment and cooled in the open air)

INTERIOR SURFACE COLOR: dark reddish-brown; fire clouds on the rim, body, and base

EXTERIOR SURFACE COLOR: dark reddish-brown; fire clouds on the body and base

WALL THICKNESS (IN MM): rim, $4.6 \mathrm{~mm}$; body, $5.4 \mathrm{~mm}$; base, $5.8 \mathrm{~mm}$ 
INTERIOR SURFACE TREATMENT: smoothed

EXTERIOR SURFACE TREATMENT: smoothed

HEIGHT (IN CM): 5.7

ORIFICE DIAMETER (IN CM): 12.1

DIAMETER AT BOTTOM OF RIM OR NECK (IN CM): N/A

BASE DIAMETER (IN CM) AND SHAPE OF BASE: N/A (missing)

ESTIMATED VOLUME (IN LITERS): 0.28

DECORATION (INCLUDING MOTIF AND ELEMENTS WHEN APPARENT): The rim of the bowl has three horizontal engraved lines, while the vessel body has a series of panels defined by three or four closely-spaced diagonal engraved lines. The panels are filled with a series of engraved nested triangle elements (Figure 8).

PIGMENT USE AND LOCATION ON VESSEL: none

TYPE AND VARIETY (IF KNOWN): Spiro Engraved

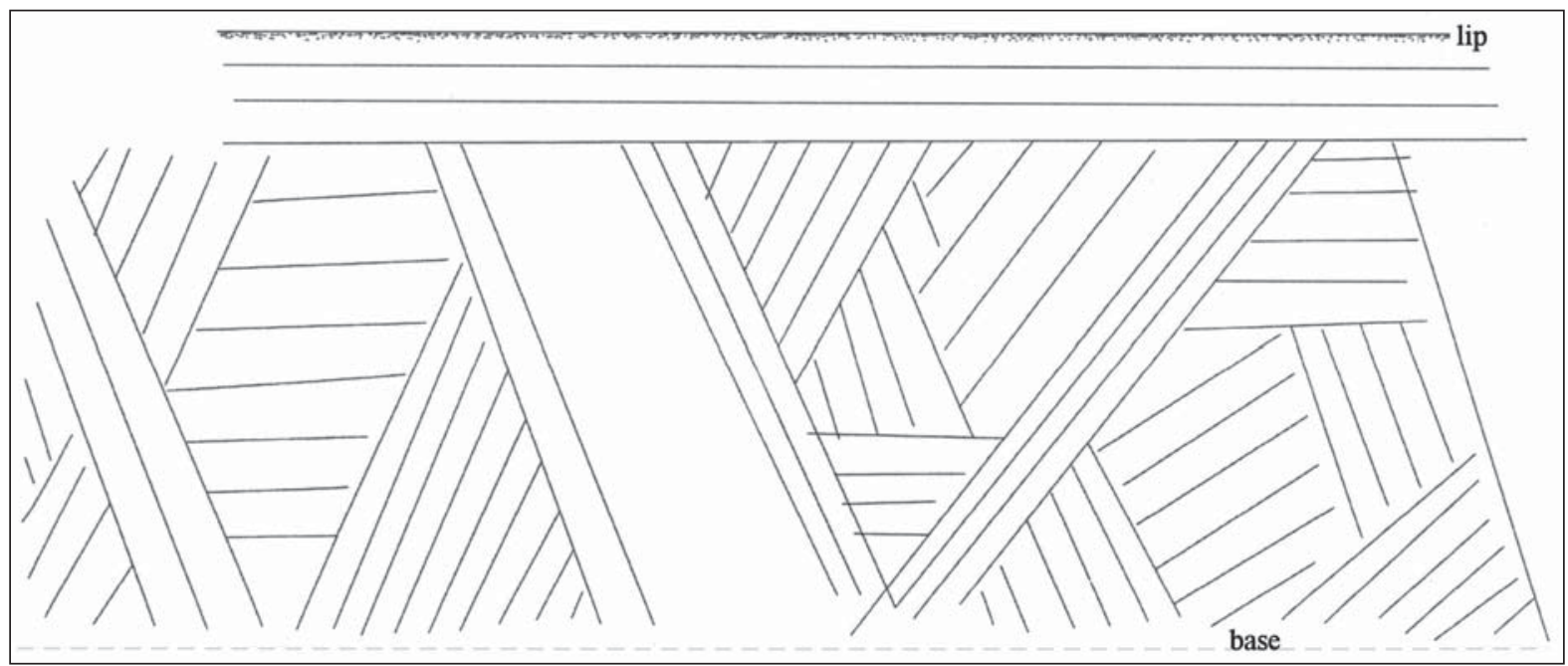

Figure 8. Decorative elements on Spiro Engraved bowl from the Frank Norris Farm site (41RR2).

The ceramic vessels from the Frank Norris Farm site can be readily sorted into two groups based on decorative styles and the use of either grog, bone, or shell as temper during vessel manufacture. The grog$(\mathrm{n}=8)$ and bone-tempered $(\mathrm{n}=1)$ vessels are from Early Caddo Albion phase (ca. A.D. 900-1100) burials (e.g., Perttula 2008:Table 1). According to Perttula (2008:322), during this period "a wide variety of finely made ceramics were made by the prehistoric Caddo peoples. Many of the ceramics were quite elaborately decorated." Well-known Albion phase sites in this part of the Red River valley include the Bentsen-Clark site (41RR41) (Banks and Winters 1975) and the Holdeman site (41RR11, Perino 1995). At the Frank Norris Farm site, the vessels from this burial component include a fingernail punctated jar, a tool punctated jar, a Hickory Engraved beaker and a bottle, one Holly Fine Engraved carinated bowl, a Kiam Incised jar, a Sanders Slipped bottle, a Spiro Engraved bottle, and a Spiro Engraved bowl. 
The shell-tempered group of vessels $(\mathrm{n}=3)$ include a Nash Neck Banded jar, a Keno Trailed bowl, and an engraved jar of unknown type. These vessels are from late McCurtain (ca. A.D. 1500-1700) phase Caddo burials apparently excavated by W. A. Rikard.

\section{Ceramic Sherd Assemblage}

The collection of ceramic sherds from the Frank Norris Farm site in the TARL collections includes 396 sherds from plain, utility, and fine ware vessels (Table 1) from Mound No. 1, Mound No. 2, from surface and ca. $0-25 \mathrm{~cm}$ bs contexts from the ridge south of Mound No. 3, and from general site contexts collected by W. A. Rikard. The plain ware sherds comprise 72.3 percent of the vessel sherds, followed by 15.0 percent that are utility ware sherds, and the remaining 12.7 percent of the sherds are from fine ware vessels.

Table 1. Ceramic sherds from the Frank Norris Farm (41RR2).

\begin{tabular}{|c|c|c|c|c|}
\hline Areas and Wares & grog & Temper & shell & $\mathrm{N}$ \\
\hline \multicolumn{5}{|l|}{ Mound No. 1} \\
\hline Plain & 1 & - & 17 & 18 \\
\hline Utility & - & - & - & - \\
\hline Fine & 1 & 1 & 3 & 5 \\
\hline Subtotal & 2 & 1 & 20 & 23 \\
\hline \multicolumn{5}{|l|}{ Mound No. 2} \\
\hline Plain & 10 & 4 & 29 & 43 \\
\hline Utility & 2 & - & 1 & 3 \\
\hline Fine & 1 & - & 2 & 3 \\
\hline Subtotal & 13 & 4 & 32 & 49 \\
\hline \multicolumn{5}{|c|}{ Ridge south of Mound No. 3} \\
\hline Plain & 16 & - & 9 & 25 \\
\hline Utility & - & 1 & 11 & 12 \\
\hline Fine & 8 & - & 5 & 13 \\
\hline Subtotal & 24 & 1 & 25 & 50 \\
\hline \multicolumn{5}{|c|}{ W. A. Rikard Collection } \\
\hline Plain & 111 & 15 & 77 & 203 \\
\hline Utility & 14 & - & 28 & 42 \\
\hline Fine & 10 & - & 19 & 29 \\
\hline Subtotal & 135 & 15 & 124 & 274 \\
\hline Totals & 174 & 21 & 201 & 396 \\
\hline
\end{tabular}

Approximately 51 percent of the ceramic vessel sherds from the site are from post-A.D. 1300 shell-tempered wares; 64.5 percent of the decorated sherds are from shell-tempered utility ware and fine ware vessels. Shell-tempered ceramic sherds are particularly common on the surface of Mound No. 1 ( 87 percent of the sherds) and Mound No. 2 (65 percent of the sherds). Another 44 percent of the sherds are from grog-tempered vessels, and only 5.3 percent are from bone-tempered vessels (see Table 1); these vessel sherds are from earlier, pre-A.D. 1300 (or even pre-A.D. 1100, based on the burial vessels in the TARL collections) Caddo occupations. Among the plain wares in the assemblage is a possible fragmentary effigy attachment to an effigy bowl (shell-tempered) as well as a shell-tempered strap handle; both of these sherds are from the ridge south of Mound No. 3. Another plain shell-tempered sherd is a rim from a carinated bowl with a 
narrow and sharply inward-turned rim panel. This is likely from a Simms Plain-like vessel (cf. Suhm and Jelks 1962:141).

The grog- and bone-tempered vessel sherds with decorative elements $(\mathrm{n}=38)$ comprise 35.5 percent of the decorated sherd assemblage from the Frank Norris Farm site (Table 2). These are relatively equally divided between decorated sherds from utility ware vessels (45 percent) and decorated sherds from fine ware vessels (55 percent), although rim sherds from utility ware vessels are slightly more common than those from fine ware vessels.

Table 2. Decorative methods and elements on grog- and bone-tempered sherds from the Frank Norris Farm site (41RR2).

\begin{tabular}{llll}
\hline $\begin{array}{l}\text { Decorative method and } \\
\text { Decorative elements }\end{array}$ & Rim & Body & $\mathrm{N}$ \\
\hline
\end{tabular}

Utility Ware

Appliqued

diagonal appliqued ridge

horizontal appliqued fillet

straight appliqued fillet

$\begin{array}{ll}- & 1 \\ - & 1 \\ 2 & 2\end{array}$

\section{Incised}

cross-hatched lines

diagonal lines

diagonal opposed lines

parallel lines

Incised-Punctated

parallel incised lines and adjacent zone of circular punctates

parallel incised lines and adjacent zone of fingernail punctates

Neck Banded*

horizontal neck bands

Punctated

fingernail punctated rows

tool punctated rows

$\begin{array}{lll}- & 2 & 2 \\ - & 2 & 2\end{array}$

Subtotal, Utility Ware

\section{Fine Ware}

Engraved

curvilinear lines

diagonal lines and nested triangle el.

hatched engraved zone

horizontal engraved line

horizontal and diagonal engraved lines

horizontal, curvilinear, and excised lines and

(3)

2

hatched zone 
Table 2. Decorative methods and elements on grog- and bone-tempered sherds from the Frank Norris Farm site (41RR2), cont.

\begin{tabular}{|c|c|c|c|}
\hline $\begin{array}{l}\text { Decorative method and } \\
\text { Decorative elements }\end{array}$ & Rim & Body & $\mathrm{N}$ \\
\hline $\begin{array}{l}\text { horizontal and diagonal lines and diagonal } \\
\text { hatched zone }\end{array}$ & 1 & - & 1 \\
\hline parallel engraved lines & - & 3 & 3 \\
\hline straight engraved line/ext. red-slipped & - & 1 & 1 \\
\hline \multicolumn{4}{|l|}{ Red-Slipped } \\
\hline int./ext. red-slipped & - & 7 & 7 \\
\hline \multicolumn{4}{|l|}{ Trailed $^{*}$} \\
\hline diagonal and opposed trailed lines & - & 1 & 1 \\
\hline parallel trailed lines & - & 1 & 1 \\
\hline Subtotal, Fine Ware & 3 & 18 & 21 \\
\hline Totals & 7 & 31 & 38 \\
\hline
\end{tabular}

*These sherds are associated with the post-A.D. 1300 Caddo ceramic assemblage, based on their decorative elements, although they are not shell-tempered

The most common of the decorated utility ware sherds have incised lines (35 percent), with simple motifs with cross-hatched lines or geometric elements, including diagonal opposed lines (Figure 9a). These sherds are likely from Canton Incised vessels. The two body sherds with incised-punctated decorative elements are likely also from Canton Incised vessels with incised triangle elements filled with punctations (see Suhm and Jelks 1962:Plate 12). About 23.5 percent of the sherds have appliqued decorative elements - including a rim with a horizontal appliqued fillet (Figure 9b), and another 23.5 percent of the decorated utility ware sherds are from Monkstown Fingernail Impressed jars that have rows of fingernail or tool punctates on the rim and/or vessel body.

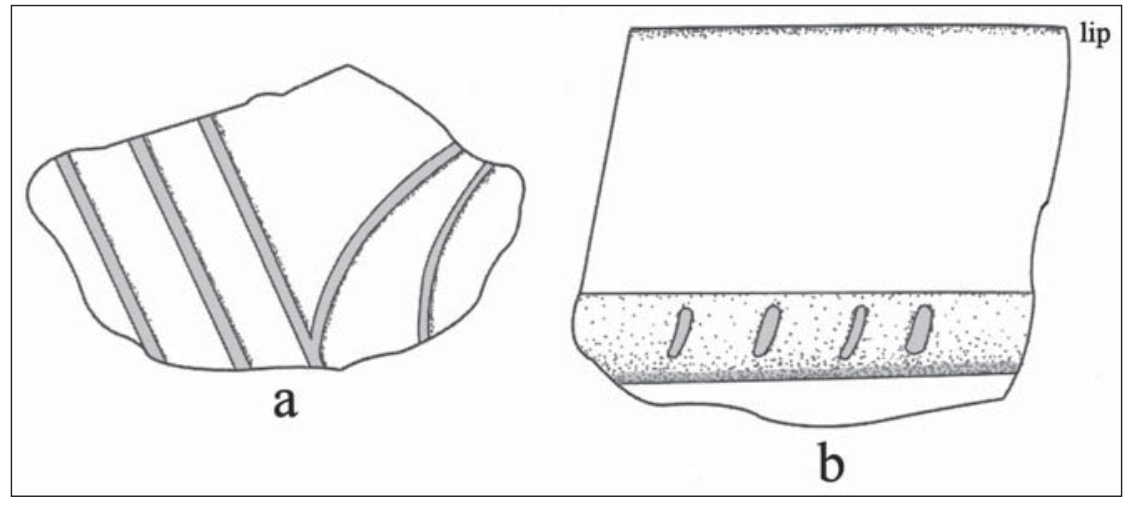

Figure 9. Selected decorative elements on utility ware sherds from the Frank Norris Farm site: a, diagonal opposed incised body sherd; b, horizontal appliqued fillets on a rim sherd.

The engraved sherds from grog- or bone-tempered vessels primarily have geometric elements featuring horizontal lines, diagonal lines, nested triangles (Figure 10a), or hatched zones (Figure 10b, d) in association with diagonal or curvilinear lines. Only 16.7 percent of the engraved sherds have curvilinear lines or elements (see Table 2). One grog-tempered body sherd with diagonal engraved lines and a nested triangle 
element may be from a Holly Fine Engraved vessel (Figure 10a), but none of the other engraved rim and body sherds can be typologically identified at this time.

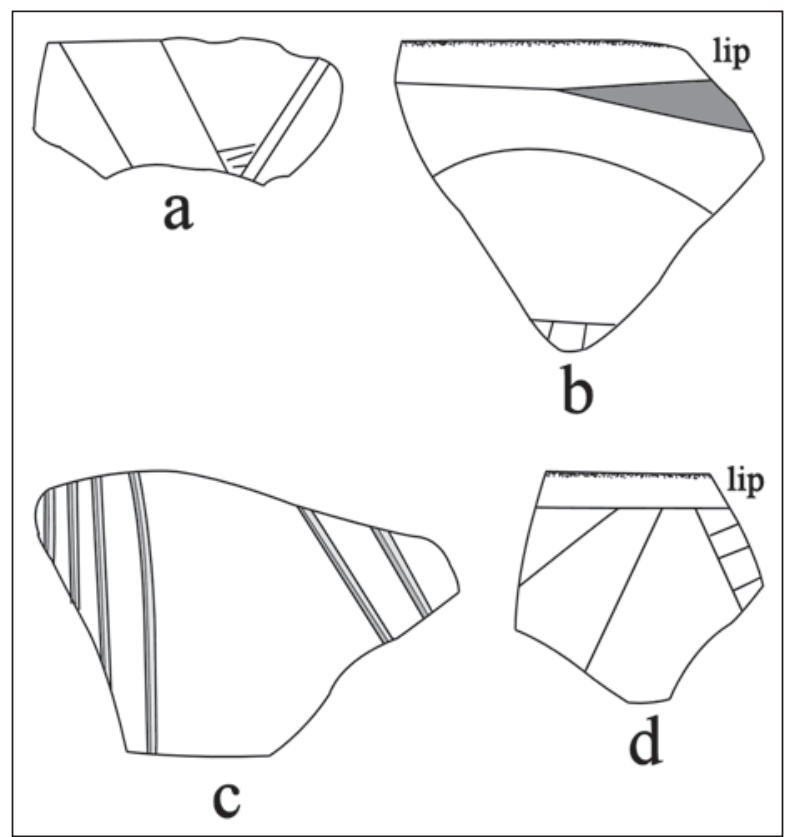

Figure 10. Selected decorative elements on fine ware sherds from the Frank Norris Farm site: a-b, d, engraved rim and body sherds; c, trailed bottle sherd.

Red-slipped grog- or bone-tempered sherds $(\mathrm{n}=7)$ in the Frank Norris Farm ceramic assemblage are from Sanders Plain or Sanders Slipped vessels; they comprise 33 percent of the fine wares (see Table 2). As redefined by Brown (1996:401-403 and Figures 2-191, 2-34g, 2-37a-1, 2-38d, 2-39d, k, n-q, and 2-42b), Sanders Plain is a grog-tempered, slipped, and undecorated type found widely across the Caddo area. Vessel forms include bowls, carinated bowls, and narrow and wide-mouthed bottles. Grog and/or bone-tempered red-slipped fine wares are a common part of ancestral Caddo ceramic assemblages in several parts of East Texas, most notably in sites in the middle Red River, the Big Cypress Creek basin, the upper Sulphur and Sabine River basin, and the middle Sabine River basin (Perttula 2015:Figure 3). Pre-A.D. 1300/1400 ceramic assemblages where redslipped sherds are relatively abundant are well represented along the Red River, particularly at sites such as Sam Kaufman (41RR16), A. C. Mackin (41LR31), Harling (41FN1), and Sanders (41LR2). The relative proportion of red-slipped sherds in the Frank Norris Farm ceramic assemblage suggests that some portion of the Caddo occupation may have been during the Sanders phase (ca. A.D. 1100-1300), when grog- or bone-tempered redslipped fine ware vessels were particularly common in mid-Red River basin Caddo sites.

Three of the decorated grog-tempered sherds (7.9 percent of the grog- and bone-tempered vessel sherds) are from post-A.D. $1300 \mathrm{McCurtain}$ phase ceramic vessels. These include a grog-tempered variety of Nash Neck Banded with horizontal neck banded rows and two trailed sherds from Keno Trailed vessels (see Table 2); one of these is a bottle sherd from the ridge south of Mound No. 3 (see Figure 10c). The presence of Keno Trailed vessel sherds - including both grog- or shell-tempered vessels (see below) - in the vessel assemblage suggests that the McCurtain phase occupation was late in the Late Caddo period, after ca. A.D. 1500 (Perttula 2008:Table 1).

About 58 percent of the decorated shell-tempered vessel sherds from the Frank Norris Farm are from utility ware vessels (Table 3 ). Sherds with appliqued (42.5 percent of shell-tempered decorated sherds) elements are most common, followed by sherds with punctated ( 30 percent) and neck banded ( 20 percent) 
decorations. These sherds are from Nash Neck Banded and Emory Punctated-Incised jars. The few incised sherds are likely also from Emory Punctated-Incised vessels, as is the incised-punctated body sherd.

Table 3. Decorative methods and elements on shell-tempered sherds from the Frank Norris Farm site (41RR2).

Decorative method and

Rim Body

$\mathrm{N}$

Decorative elements

Utility Ware

Appliqued

node

straight appliqued fillet

straight appliqued ridge

vertical appliqued ridge

$\begin{array}{lll}- & 13 & 13\end{array}$

$\begin{array}{lll}- & 2 & 2\end{array}$

Incised

parallel lines

Incised-Punctated

parallel incised lines and adjacent tool punctated zone

$-$

\section{Neck Banded}

horizontal neck banded

3

5

8

Punctated

fingernail punctated rows

horizontal tool punctated row

linear tool punctated rows

tool punctated rows

13

Subtotal, Utility Ware

Fine Ware

Engraved

curvilinear excised zone

curvilinear zone filled with incised lines

curvilinear and rectilinear hatched zones

diagonal and curvilinear lines with excised tick marks

horizontal and curvilinear lines and circle el.

$\begin{array}{lll}- & 1 & 1 \\ - & 3 & 3 \\ - & 1 & 1 \\ 1 & - & 1 \\ 1 & - & 1\end{array}$

\section{Red-Slipped}

ext. red-slipped

$\begin{array}{lll}- & 4 & 4\end{array}$

int./ext. red-slipped

\section{Trailed}

curvilinear trailed line

Subtotal, Fine Ware

Totals

2

27

29

10

59

69


Nash Neck Banded jars have horizontal rows of corrugated neck bands on the rim, as well as appliqued elements (nodes, ridges, and fillets) on both rim and body portions of vessels (Suhm and Jelks 1962:Plate 56) (Figure 11f). Neck banded jars are a common utility ware in a number of ancestral Caddo communities occupied after ca. A.D. 1300 in East Texas (Perttula 2015:Figure 10), including both grog-bone and shell-tempered varieties. The highest proportions (23.6-79.6 percent of the decorated sherd assemblage) of neck banded sherds (shell-tempered) occur in ca. A.D. 1300-1680 McCurtain phase assemblages on the middle reaches of the Red River. Shell-tempered neck banded sherds (Nash Neck Banded) are also found in high percentages at other sites on the same age in other Red River communities both upstream and downstream from the McCurtain phase sites; as at the Frank Norris Farm site, both grog/bone and shell-tempered neck banded sherds are found in these areas.

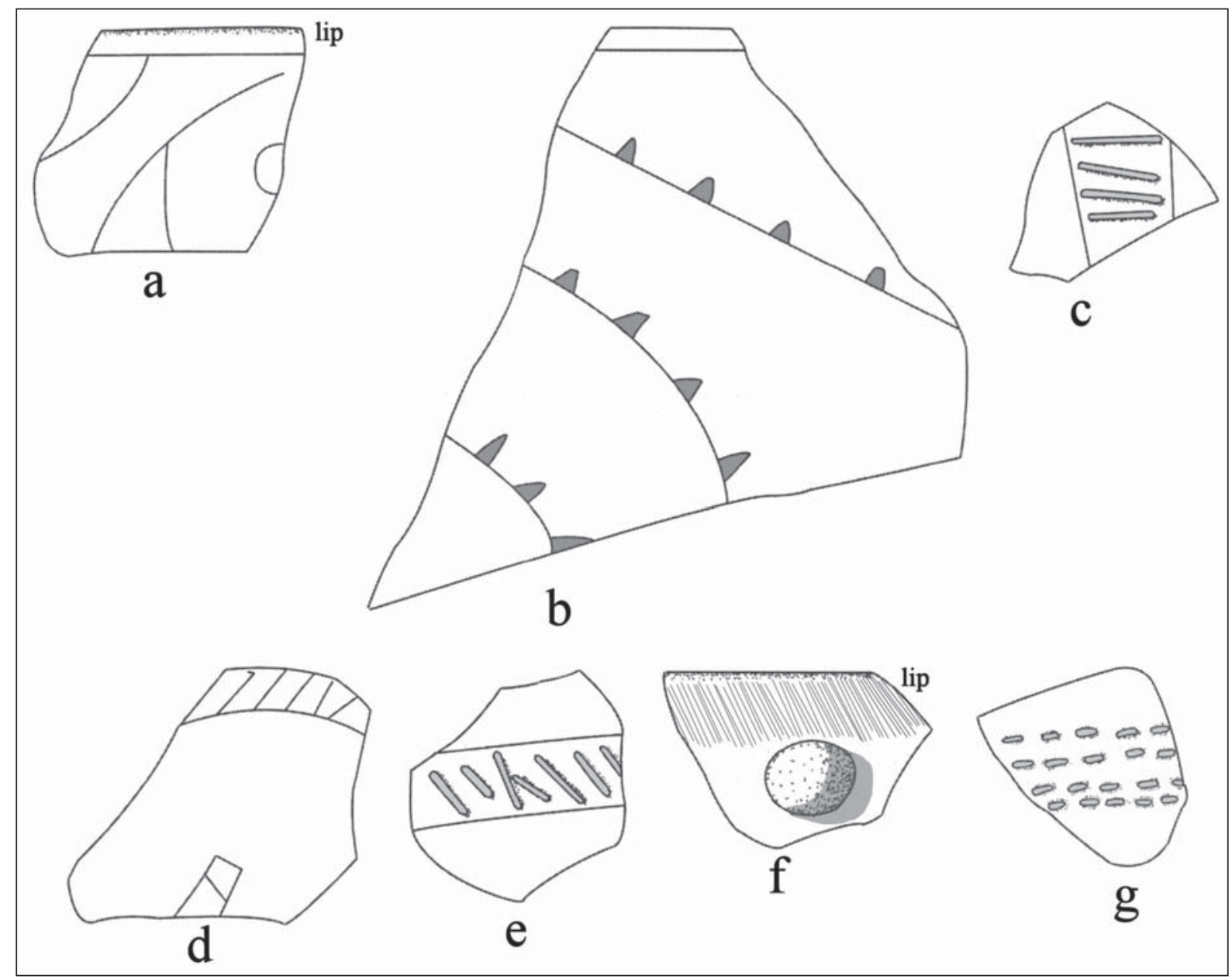

Figure 11. Selected decorative elements on shell-tempered utility ware and fine ware sherds from the Frank Norris Farm site: a-b, Avery Engraved rim sherd; c, e, Hudson Engraved; d, hatched engraved zones; f, appliqued node; g, linear tool punctated body sherd.

Emory Punctated-Incised was defined in print by Story et al. (1967:136-138) from sherds recovered at the 18th century Gilbert site. The type occurs in both prehistoric and historic Caddo contexts, based primarily on a large assemblage of McCurtain phase vessels from sites on the Red River in East Texas and Southeast Oklahoma. According to Story et al. (1967:137), Emory Punctated-Incised occurs as jars tempered with sand, sand-shell, sand and grog, or sand and bone. "Some vessels have only punctations arranged into one to four rows around the vessel, usually just below the lip. If brushing is present, it may occur almost anywhere on the vessel, from the lip to the base. If incising is present, it usually consists of straight to slightly curved lines 
extending from below the rim to the base or to about the middle of the body. Punctations are often combined with either incising or brushing" (Story et al. 1967:137). Red River varieties of Emory Punctated-Incised commonly also include appliqued elements on the vessel bodies as well as horizontal row of punctates on the rim. The Emory Punctated-Incised sherds from the Frank Norris Farm site have fingernail, tool, and linear (see Figure 11g) tool punctated rows on the rim and/or vessel body.

Shell-tempered red-slipped fine ware sherds like those from the Frank Norris Farm site (see Table 3) are common in post-A.D. 1300/1400 ceramic assemblages along portions of the Red River, most notably as Clement Redware (see Flynn 1976) in McCurtain phase sites on the middle reaches of the Red River. Here, the red-slipped sherds represent 65.5 percent of the shell-tempered fine ware sherds at the site. Other red-slipped shell-tempered sherds are likely from the otherwise undecorated portions of Avery Engraved deep bowls, carinated bowls, and bottles.

The shell-tempered engraved sherds from the site are from Avery Engraved ( $\mathrm{n}=3$, see Figure 11a-b) and Hudson Engraved (n=3, see Figure 11c, e) vessels; several of the Avery Engraved sherds have a red slip on both vessel surfaces. Hudson Engraved is most commonly seen in post-A.D. 1500 McCurtain phase sites along the Red River. One other engraved body sherd, from an unidentified fine ware type, also with interior and exterior red-slipped surfaces, has straight and curvilinear hatched zones (see Figure 11d).

The shell-tempered trailed sherds from the Frank Norris Farm site have curvilinear trailed lines (see Table 3). Sherds with trailed decorative elements, likely from Keno Trailed bowls and bottles (see Suhm and Jelks 1962), are found in only a few parts of East Texas, principally in sites on the Red River (Perttula 2015:Figure 4). These sites generally date after ca. A.D. 1500 (or later) to A.D. 1730.

\section{SUMMARY AND CONCLUSIONS}

The Frank Norris Farm site (41RR2) was an ancestral Caddo mound, village, and cemetery occupation along the Red River in East Texas. When the site was first investigated by University of Texas (UT) archaeologists in 1930, it was reported to have three mounds, with surrounding habitation areas and cemeteries extending to the bank of the Red River. The site was the scene of extensive looting of Caddo burials in the first half of the 1930s, and erosion of the site by the Red River had destroyed the site by 1936 .

The TARL collections from the Frank Norris Farm site include vessels from burials excavated in the village by both UT archaeologists and W. A. Rikard, a local avocational archaeologist, as well as almost 400 sherds from plain ware, utility ware, and fine ware vessels. The decorative styles identified on the vessels and decorated sherds, as well as the tempers used in vessel manufacture suggest that the Frank Norris Farm site was used as a cemetery area during the Early Caddo period (ca. A.D. 900-1100), as a settlement during the Sanders phase (ca. A.D. 1100-1300), and as a settlement and cemetery during the latter part of the McCurtain phase (ca. A.D. 1500-1700). It is not clear when the three mounds were constructed at the site, although the common occurrence of post-ca. A.D. 1300 shell-tempered sherds collected from the surface of Mounds No. 1 and No. 2 by UT archaeologists at least indicates that these mounds were likely used during the McCurtain phase occupation.

At the Frank Norris Farm site, the vessels from the ca. A.D. 900-1100 burial component include a fingernail punctated jar, a tool punctated jar, a Hickory Engraved beaker and a bottle, one Holly Fine Engraved carinated bowl, a Kiam Incised jar, a Sanders Slipped bottle, a Spiro Engraved bottle and a Spiro Engraved bowl. The ca. A.D. 1100-1300 component has Sanders Slipped, Canton Incised, and Monkstown Fingernail Impressed sherds from fine ware and utility ware vessels, but no Sanders Engraved sherds were identified in the ceramic assemblage.

The last component, dating to late McCurtain phase times (ca. A.D. 1500-1700), includes shell-tempered vessels $(n=3)$ of Nash Neck Banded, a Keno Trailed bowl, and an engraved jar of unknown type. These 
vessels are from late McCurtain phase Caddo burials apparently excavated by W. A. Rikard. The decorated ceramic sherds from this component include shell-tempered and grog-tempered Nash Neck Banded vessels, shell-tempered Emory Punctated-Incised jars, as well as shell-tempered Avery Engraved and Hudson Engraved fine ware vessels, and both shell-tempered and grog-tempered Keno Trailed bottles and bowls.

\section{ACKNOWLEDGMENTS}

We appreciate the access to site records and collections provided by Jonathan Jarvis at TARL. Lance Trask prepared the various figures, except for the vessel photo of the effigy bowl, which was provided by Robert Z. Selden Jr.

\section{REFERENCES CITED}

Banks, L. D. and J. Winters

1975 The Bentsen-Clark Site, Red River County, Texas: A Preliminary Report. Special Publication No. 2. Texas Archeological Society, San Antonio.

Brown, J. A.

1996 The Spiro Ceremonial Center. The Archaeology of Arkansas Valley Caddoan Culture in Eastern Oklahoma. 2 Vols. Memoir No. 29. Museum of Anthropology, University of Michigan, Ann Arbor.

Flynn, P.

1976 A Study of Red-Filmed Pottery from the Clement Site (Mc-8), McCurtain County, Oklahoma. Bulletin of the Oklahoma Anthropological Society 25:127-134.

Hampton, H. and G. Moore

1936 A Burial Site in Northeastern Red River County. Central Texas Archeologist 2:64-68.

Perino, G.

1995 The Dan Holdeman Site (41RR11), Red River County, Texas. Journal of Northeast Texas Archaeology 6:3-65.

Perttula, T. K.

2008 The Archeology of the Roitsch Site (41RR16), an Early to Historic Caddo Period Village on the Red River in Northeast Texas. In Collected Papers from Past Texas Archeological Society Summer Field Schools, edited by T. K. Perttula, pp. 313-628. Special Publication No. 5. Texas Archeological Society, San Antonio.

2015 East Texas Caddo Ceramic Sherd Database. Journal of Northeast Texas Archaeology 51:1-46.

Skinner, S. A., R. K. Harris, and K. M. Anderson (editors)

1969 Archaeological Investigations at the Sam Kaufman Site, Red River County, Texas. Contributions in Anthropology No. 5. Department of Anthropology, Southern Methodist University, Dallas.

Story, D. A., B. Barber, E. Cobb, H. Cobb, R. Coleman, K. Gilmore, R. K. Harris, and N. Hoffrichter

1967 Pottery Vessels. In "The Gilbert Site: A Norteno Focus Site in Northeast Texas," edited by E. B. Jelks. Bulletin of the Texas Archeological Society 37:112-187.

Suhm, D. A. and E. B. Jelks (editors)

1962 Handbook of Texas Archeology: Type Descriptions. Special Publication No. 1, Texas Archeological Society, and Bulletin No. 4, Texas Memorial Museum, Austin. Reprinted in 2009, Gustav's Library, Davenport, Iowa. 